See discussions, stats, and author profiles for this publication at: https://www.researchgate.net/publication/325076116

\title{
Forage Characteristics of Bermudagrass Pastures Overseeded with Pintoi Peanut and Grazed at Different Stubble Heights
}

Article in Crop Science · July 2018

DOl: 10.2135 /cropsci2018.01.0007

CITATIONS

0

11 authors, including:

Joao Sanchez

University of Florida

16 PUBLICATIONS 23 CITATIONS

SEE PROFILE

Lynn E Sollenberger

University of Florida

340 PUBLICATIONS 3,517 CITATIONS

SEE PROFILE

Some of the authors of this publication are also working on these related projects:
READS

135

Joao M. B. Vendramini

University of Florida

171 PUBLICATIONS 1,025 CITATIONS

SEE PROFILE

Maria L. Silveira

University of Florida

111 PUBLICATIONS 1,089 CITATIONS

SEE PROFILE

Project Effect of olive oil bioextracts on weaned female angus calves induced to a low-grade chronic inflammation View project

Production and mineral composition of Urochloa brizantha cv. Xaraés fertilized with nitrogen sources View project 


\title{
Forage Characteristics of Bermudagrass Pastures Overseeded with Pintoi Peanut and Grazed at Different Stubble Heights
}

\author{
Joao M. D. Sanchez, Joao M. B. Vendramini, ${ }^{\star}$ Lynn E. Sollenberger, Maria L. Silveira, Jose C. B. Dubeux, \\ Jr., Philipe Moriel, Frank A. Kuwahara, Ulysses Cecato, James K. Yarborough, Cecilio V. Soares Filho, \\ and Fabio C. Leite de Oliveira
}

\begin{abstract}
Overseeding warm-season legumes into warmseason perennial grass pastures may increase productivity and nutritive value of pastures in tropical and subtropical regions. The objective of this study was to investigate the effects of overseeding 'Amarillo' pintoi peanut (Arachis pintoi Krapov. \& W.C. Greg.) into Jiggs bermudagrass [Cynodon dactylon (L.) Pers.] pastures grazed at different stubble heights. The experiment was conducted in Ona, FL, from June to October in 2014 and 2015. Treatments were a split-plot design of two sward types (bermudagrass monocultures or overseeded with pintoi peanut, main plots) and two postgrazing stubble heights ( 15 or $25 \mathrm{~cm}$ [SH15 and SH25], subplots) arranged in a randomized complete block design with four replicates. Pastures were mob stocked, with 28-d resting periods between grazing events. There was no effect of stubble height on pintoi peanut plant density (5.8 plants $\mathrm{m}^{-2}$ ), ground cover (5.8\%), or proportion in the herbage mass (HM, 5.2\%); however, proportion in the HM increased from 1.1 to $8.2 \%$ over $2 \mathrm{yr}$. There was no effect of sward type on weed ground cover; however, $\mathrm{SH} 25$ had greater weed ground cover than $\mathrm{SH} 15$ (53.4 vs. $18.2 \%)$. Herbage accumulation rate, crude protein, and in vitro digestible organic matter were not affected by sward type $\left(23.4 \mathrm{~kg} \mathrm{ha}^{-1} \mathrm{~d}^{-1}, 101 \mathrm{~g}\right.$ $\mathrm{kg}^{-1}$, and $431 \mathrm{~g} \mathrm{~kg}^{-1}$, respectively). Pintoi peanut proportion in the HM increased over time; however, it may take $>2 \mathrm{yr}$ to have a significant presence of pintoi peanut in the mixed sward.
\end{abstract}

J.M.D. Sanchez, J.M.B. Vendramini, M.L. Silveira, P. Moriel, and J.K. Yarborough, Range Cattle Research and Education Center, Univ. of Florida, Ona, FL 33865; J.M.D. Sanchez, CAPES scholarship holder, process BEX 11975/13-0, CAPES Foundation, Ministry of Education of Brazil, Brasilia, DF, 70040-020, Brazil; L.E. Sollenberger, Dep. of Agronomy, Univ. of Florida, Gainesville, FL 32611; J.C.B. Dubeux, Jr., North Florida Research and Education Center, Marianna, FL 32446; F.A. Kuwahara, Dep. of Animal Breeding and Nutrition, São Paulo State Univ., Botucatu, São Paulo, Brazil 18618-000; U. Cecato and F.C. Leite de Oliveira, Dep. of Animal Science, Maringa State Univ., Maringa, Paraná, Brazil 87020-900; C.V. Soares Filho, Dep. of Animal Support, Production and Health, São Paulo State Univ., Aracatuba, São Paulo, Brazil 16050-680. ^Corresponding author (jv@ufl.edu). Received 4 Jan. 2018. Accepted 5 Mar. 2018. Assigned to Associate Editor Jamie Foster Malone.

Abbreviations: $\mathrm{CP}$, crude protein; HAR, herbage accumulation rate; HM, herbage mass; IVDOM, in vitro digestible organic matter; LI, light interception; LW, live weight; SH15, average stubble height of $15 \mathrm{~cm}$; SH25, average stubble height of $25 \mathrm{~cm}$.

$\mathrm{B}$ ermudagrass [Cynodon dactylon (L.) Pers.] is the most planted forage species in the southeastern United States (Taliaferro et al., 2004). Jiggs bermudagrass is one of the few bermudagrass genotypes that tolerate poorly drained soils, and it has been widely used by livestock producers in the US Gulf Coast region (Newman et al., 2014). However, it is known that warm-season perennial grass pastures require $\mathrm{N}$ fertilization to be productive and persistent under grazing (Thomas, 1992). Limited use of fertilizer in pastures grazed by beef cattle, due to increased fertilizer prices, might lead to a reduction in forage production, nutritive value, and persistence (Blue et al., 1980; Boddey et al., 1997).

Mixing legumes into warm-season perennial grass pastures is an effective alternative management practice to supply $\mathrm{N}$ and increase forage nutritive value (Thomas, 1995). However, lack of

Published in Crop Sci. 58:1-9 (2018).

doi: 10.2135/cropsci2018.01.0007

(C) Crop Science Society of America 5585 Guilford Rd., Madison, WI 53711 USA All rights reserved. 
persistence has limited the use of warm-season legumes in tropical and subtropical regions. Pitman et al. (1988) evaluated 50 warm-season legume accessions in Florida and observed that most had limited persistence under grazing. The authors also observed that persistence was affected by the interactions between legume species and grazing intensity. Rhizoma peanut (Arachis glabrata Benth.) is a persistent and productive warm-season perennial legume used in Florida; however, vegetative propagation and slow establishment are limiting factors for its use in grazing systems (Castillo et al., 2013, 2014; Mullenix et al., 2014).

Pintoi peanut (Arachis pintoi Krapov. \& W.C. Greg.) is a warm-season perennial legume that has been studied in South America during recent decades, with documented persistence under grazing on acidic and low-fertility soils (Rao and Kerridge, 1994). Pintoi peanut produces reasonable amounts of viable seeds, with some genotypes producing $>1 \mathrm{Mg} \mathrm{ha}^{-1}$ (Carvalho and Quesenberry, 2012). Seed production is a desirable characteristic for propagation and persistence under grazing and also an advantage when compared with rhizoma peanut. Ribeiro et al. (2012) observed that pintoi peanut was persistent under grazing when mixed with 'Coast-cross' bermudagrass under continuous stocking.

Grazing intensity is one of the main factors affecting forage production and nutritive value (Sollenberger et al., 2012). Sinclair et al. (2007) reported that 'Amarillo' pintoi peanut persisted under clipping at different stubble heights and frequencies when mixed with kikuyugrass (Pennisetum clandestinum Hochst. ex Chiov.) or rhodesgrass (Chloris gayana Kunth) in Australia. de Andrade et al. (2012) observed that pintoi peanut proportion in a palisadegrass [Urochloa brizantha (Hocht. Ex A. Rich.) RD Webster]-pintoi peanut mixed pasture increased as grazing height decreased from 35 to $20 \mathrm{~cm}$. The authors concluded that pintoi peanut is more competitive when grazed more intensively. Aguiar et al. (2014) observed that grazing Jiggs bermudagrass pastures below $17-\mathrm{cm}$ stubble height decreased its ground cover and increased the incidence of weeds in comparison with taller grazing heights. However, there is limited information about the persistence of pintoi peanut in grass-legume mixtures with bermudagrass in subtropical regions. Furthermore, the optimum grazing stubble height for bermudagrass pastures overseeded with pintoi peanut has not been determined.

The objective of this experiment was to evaluate the effect of overseeding Amarillo pintoi peanut into Jiggs bermudagrass pastures managed at different grazing intensities. It was hypothesized that pintoi peanut will persist when overseeded in bermudagrass pastures, and it will represent a greater proportion of the mixture when grazed at shorter stubble heights. Additionally, bermudagrass pastures overseeded with pintoi peanut will have greater productivity and nutritive value than bermudagrass monocultures.

\section{MATERIAL AND METHODS Experimental Site}

The study was conducted at the Range Cattle Research and Education Center, Ona, FL $\left(27^{\circ} 26^{\prime} \mathrm{N} 82^{\circ} 55^{\prime} \mathrm{W}\right)$ from June to October (112 d) of 2014 and 2015. The predominant soil was a Pomona fine sand (sandy, siliceous, hyperthermic Ultic Alaquods). Prior to initiation of the grazing trial, mean soil $\mathrm{pH}$ (in water) was 5.9. Mehlich-1 extractable $\mathrm{P}, \mathrm{K}, \mathrm{Mg}$, and $\mathrm{Ca}$ concentrations in the Ap horizon (0- to 15-cm depth) were 15, 41,270 , and $850 \mathrm{mg} \mathrm{kg}^{-1}$, respectively.

\section{Treatments and Experimental Design}

Treatments were a split-plot design of two sward types (Jiggs bermudagrass monocultures or overseeded with Amarillo pintoi peanut, main plots) and two postgrazing stubble heights (15 or $25 \mathrm{~cm}$; [SH15 and SH25, respectively]; subplots) with main plots arranged in a randomized complete block design with four replicates. Amarillo was chosen because it is the only forage cultivar of pintoi peanut with commercially available seeds in the United States. The shorter stubble height was based on the optimum grazing stubble height for Jiggs bermudagrass, according to Aguiar et al. (2014), whereas the taller stubble height was chosen to provide minimum defoliation. Overall stubble height averages for the two experimental years were 14.8 and $22.0 \mathrm{~cm}$ for SH15 and SH25, respectively.

\section{Plot Establishment and Management}

Sixteen 0.12-ha pastures were used as experimental units. Jiggs bermudagrass pastures were established in 2010 and grazed for 2 yr. Pastures were mowed at $15-\mathrm{cm}$ stubble height and overseeded with $12 \mathrm{~kg} \mathrm{ha}^{-1}$ of pintoi peanut seeds using a no-till drill (Pasture Pleaser, Agco-Tye) in June 2013. There is limited information in the literature about seeding rates for overseeding pintoi peanut into warm-season grasses; therefore, the seeding rate in this study was based on Cook et al. (1994), which stated that $10 \mathrm{~kg} \mathrm{ha}^{-1}$ is sufficient for successful stand establishment. The seeds were inoculated with a Bradyrhizobium strain, N-DURE (INTX Microbials), at the level of $4 \mathrm{~g} \mathrm{~kg}^{-1}$ of seed.

In May 2014 and 2015, pastures were fertilized with $13 \mathrm{~kg}$ $\mathrm{P}$ and $50 \mathrm{~kg} \mathrm{~K} \mathrm{ha}^{-1}$ and $2 \mathrm{~kg} \mathrm{ha}^{-1}$ of the micronutrient mixture F-503 (24 g B kg-1, $24 \mathrm{~g} \mathrm{Cu} \mathrm{kg}^{-1}, 144 \mathrm{~g} \mathrm{Fe} \mathrm{kg}^{-1}, 60 \mathrm{~g} \mathrm{Mn} \mathrm{kg}^{-1}$, and $\left.56 \mathrm{~g} \mathrm{Zn} \mathrm{kg}^{-1}\right)$. The fertilization was based on recommendations from the University of Florida (Mylavarapu et al., 2013). Pastures were not fertilized with $\mathrm{N}$ because the potential $\mathrm{N}$ contribution from pintoi peanut to the warm-season grass was a response variable of interest, and it would likely be masked by the addition of $\mathrm{N}$ fertilizer.

Twenty-four beef heifers and 13 nonpregnant cows (Bos spp.) with body weights of $386 \pm 38$ and $505 \pm 30 \mathrm{~kg}$, respectively, were used to graze pastures to the target stubble height using the mob-stocking method. The grazing period varied from $4 \mathrm{~h}$ to $3 \mathrm{~d}$, followed by a $28-\mathrm{d}$ resting period. The variation in the grazing period was caused by differences in herbage accumulation rate (HAR) and canopy height among the different treatments and grazing cycles. Stocking density varied from 96 to 46 animal units (450 kg live weight) $\mathrm{ha}^{-1} \mathrm{~d}^{-1}$ for $4 \mathrm{~h}$ and $3 \mathrm{~d}$, respectively. Blocks were grazed consecutively (i.e., all the experimental units of a given block were grazed before animals were 
moved to the following block). This practice was used because the number of animals available for the project was not enough to graze all experimental units concurrently. In each grazing cycle, grazing in all blocks was done in $\sim 12 \mathrm{~d}$.

There was a total of four grazing cycles per year. Each grazing cycle started with the grazing event, followed by postgrazing and subsequent pregrazing measurements. The animals were maintained in adjacent pastures outside of the experimental area during the resting periods.

Pastures were sprayed with $2.3 \mathrm{~L} \mathrm{ha}^{-1}$ of carbaryl (1-naphtyl methylcarbamate) in September 2014 and June 2015 to control spittlebugs (Prosapia bicincta Say). No chemical weed control was used because there is no registered herbicide currently available for pintoi peanut crops.

\section{Response Variables Botanical Composition}

Pintoi peanut plant density, the proportion of pintoi peanut in the ground cover, and the proportion of pintoi peanut in the herbage mass (HM) were measured only in pregrazing conditions of the overseeded pastures. Plant density and ground cover were evaluated every $28 \mathrm{~d}$. A $0.25-\mathrm{m}^{2}$ ring was randomly placed in 20 locations per experimental unit, and pintoi peanut plants were counted. The proportion of ground covered by pintoi peanut, bermudagrass, and weeds was visually estimated in the same 20 locations. The proportion of pintoi peanut in HM was measured at the beginning of the experiment in 2014 and the end in 2015. Each experimental unit was sampled before grazing by clipping $250.05-\mathrm{m}^{2}$ quadrats to a $2-\mathrm{cm}$ stubble height. Samples were hand separated into pintoi peanut and other herbage.

Given the high weed presence in the area during Year 2, the proportion of weeds in ground cover and HM was evaluated at the end of the experimental period in 2015. The procedure for the evaluation of weed ground cover and proportion of weeds in HM were the same as described for pintoi peanut.

\section{Herbage Mass and Herbage Accumulation Rate}

The double sampling technique (Santillan et al., 1979) was used to determine post- and pregrazing HM every $28 \mathrm{~d}$. The indirect measure was the settling height of a $0.25-\mathrm{m}^{2}$ aluminum disk and the direct measure involved hand clipping all herbage to a $2-\mathrm{cm}$ stubble height. To calibrate the disk, 32 sites (two per experimental unit) were double sampled (i.e., both disk height and clipping) across the experiment at each HM sampling event. At each site, disk settling height was measured and forage was clipped to $2 \mathrm{~cm}$, dried at $60^{\circ} \mathrm{C}$ for $72 \mathrm{~h}$, and weighed. Herbage mass was regressed on disk height to develop a calibration equation using the PROC REG procedure of SAS (SAS Institute, 1996). Two equations (one for SH15 pastures, and the other for SH25) were used to predict pasture HM in both post- and pregrazing conditions using the average disk settling height from 20 locations per experimental unit. Herbage accumulation rate was calculated as the difference between HM in a pregrazing condition minus the previous postgrazing HM, divided by $28 \mathrm{~d}$.

\section{Canopy Height and Light Interception}

Pregrazing canopy height was evaluated with a measuring stick at 20 random locations per experimental unit. Pregrazing canopy light interception (LI) was measured using AccuPAR LP-80 ceptometer (Decagon Devices). Eight readings were taken in each experimental unit from 1000 to $1200 \mathrm{~h}$, with measurements taken when photosynthetic active radiation was at least $600 \mu \mathrm{mol} \mathrm{m} \mathrm{m}^{-2} \mathrm{~s}^{-1}$. The beam fraction sensor was placed at the center of each half of the paddock and four readings were taken from representative areas, with the probe placed at ground level. Canopy LI was calculated by dividing the transmitted by incident light, multiplying by 100, and subtracting from 100 .

\section{Nutritive Value}

Hand-plucked samples were taken from each experimental unit at the target stubble height for crude protein (CP) and in vitro digestible organic matter (IVDOM) determination. Samples were dried at $60^{\circ} \mathrm{C}$ and ground in a Wiley mill (Model 4, Thomas-Wiley Laboratory Mill, Thomas Scientific) to pass a 1-mm stainless steel screen. Samples were analyzed for IVDOM using the two-stage technique described by Tilley and Terry (1963) and modified by Moore and Mott (1974). Nitrogen concentration was determined using a micro-Kjeldahl method, with a modification of the aluminum block digestion technique described by Gallaher et al. (1975). Crude protein was determined by multiplying $\mathrm{N}$ concentration by 6.25 .

\section{Statistical Analysis}

The response variables were analyzed by fitting mixed-effect models using the MIXED procedure of SAS (SAS Institute, 1996). The model for post- and pregrazing LI, canopy height, HM, CP, IVDOM, and HAR had sward type, stubble height, month, and their interactions as fixed effects, whereas block and year were considered random effects. The fixed effects for pintoi peanut ground cover and plant density were stubble height, month, and their interaction, whereas year and block were considered random effects. For the proportion of pintoi peanut in the HM, stubble height was a fixed effect and block was random. The proportion of weeds in HM had sward type, stubble height, and their interactions as fixed effects and block as a random effect. When month was included in the model, it was analyzed as a repeated measurement, and the covariance structure was selected based on the smallest Akaike information criterion value. Normality of residues and homogeneity of variances were tested using conditional studentized residual plots, and data were transformed if ANOVA assumptions were violated. Reciprocal transformation was used in pintoi ground cover. Square root transformation was used on weed ground cover and postgrazing HM. Logarithmic transformation was used on weed ground cover. Square transformation was used on pregrazing LI and IVDOM. Means reported are nontransformed least square means. Treatments were considered different when $P \leq 0.10$ by LSD test. Pearson correlation coefficients among LI, HM, and canopy height were determined using PROC CORR of SAS.

\section{RESULTS AND DISCUSSION Weather}

Average temperatures were similar from June to September, decreasing in October, with values in both experimental years being close to the $20-y r$ average (Table 1). Monthly 
Table 1. Average monthly precipitation and temperature during the experimental period and from 1998 to 2017 at the Range Cattle Research and Education Center, Ona, FL.

\begin{tabular}{|c|c|c|c|c|c|}
\hline \multirow[b]{2}{*}{ Year } & \multicolumn{5}{|c|}{ Month } \\
\hline & June & July & Aug. & Sept. & Oct. \\
\hline & \multicolumn{5}{|c|}{ Avg. temperature } \\
\hline & & & $-{ }^{\circ} \mathrm{C}$ & 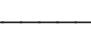 & - \\
\hline 2014 & 25.5 & 26.2 & 26.8 & 25.2 & 22.7 \\
\hline 2015 & 26.0 & 26.2 & 26.5 & 26.4 & 23.9 \\
\hline \multirow[t]{3}{*}{ 20-yr avg. } & 25.7 & 26.4 & 26.6 & 25.9 & 23.2 \\
\hline & \multicolumn{5}{|c|}{ Rainfall } \\
\hline & & & $\mathrm{mm}$ & & 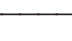 \\
\hline 2014 & 166 & 213 & 95 & 296 & 21 \\
\hline 2015 & 228 & 205 & 380 & 114 & 43 \\
\hline 20-yr avg. & 211 & 175 & 231 & 184 & 53 \\
\hline
\end{tabular}

precipitations were relatively similar in June and July in both years, with some variations observed in August and September (Table 1). Monthly precipitation in August 2014 was less than in September 2014, whereas the opposite pattern was observed in August and September 2015. The decrease in monthly precipitation in October was observed in both experimental years, and it is in agreement with the 20 -yr average. The summer growing season for tropical grasses in southern Florida has its peak from June to August (Obour et al., 2011), but temperatures and rainfall usually do not decrease until late September or early October.

\section{Botanical Composition}

Plant density and proportion of ground cover by pintoi peanut were not affected by stubble height; however, they were affected by month (Table 2). Plant density did not differ in June and July, but it was greater in August; however, September plant density was similar to June, July, and August plant densities. Similarly, ground cover was the greatest in August. The initial and final (2 yr) proportion of pintoi peanut in $\mathrm{HM}$ were not affected by stubble height (1.1 and 8.2\%, respectively; $\mathrm{SE}=3.22 ; P>0.62$ ).

Reasons for the increased density and ground cover of pintoi peanut in August were likely related to weather conditions. Although there was less rainfall in August than in September 2014, average ambient temperature in August was greater than in other months, as was the precipitation in 2015 (Table 2). The lack of stubble height effect was consistent among pintoi peanut ground cover, plant density, and proportion of HM; however, it did not correspond with previous results reported in the literature. de Andrade et al. (2012) studied the effect of different levels of herbage allowance on mixtures of 'BRS Mandobi' pintoi peanut and 'Marandu' palisadegrass. The authors reported that the proportion of the legume ranged from 9.5 to $21 \%$ at lesser herbage allowances (greater grazing intensities), whereas at greater herbage allowances, the proportion of the legume varied from 3.4 to 3.8\%. The average stubble heights for the least and greatest herbage allowances were 34.6 and $21.3 \mathrm{~cm}$, respectively. Ibrahim and 't Mannetje (1998) indicated that the proportion of pintoi peanut in mixtures with either palisadegrass or creeping signalgrass [Urochloa humidicola (Rendle) Morrone \& Zuloaga] increased as stocking rate increased (15.5 vs. $26.5 \%$ for the stocking rates of 1.75 and 3.0 animal units ha ${ }^{-1}$, respectively). Differences in canopy architecture and productivity among pintoi peanut genotypes could be a reason for the discrepancy between the present and previous results. de Assis et al. (2008) observed that Amarillo had a slightly greater soil cover than Mandobi, although it produced slightly less forage. Another factor that may have contributed to differences between our results and those of earlier studies is the use of bermudagrass in the current study vs. palissadegrass and creeping signalgrass in previous work. de Andrade et al. (2006) mentioned that Ac-01 pintoi peanut colonized the bare ground between the 'Massai' guineagrass [Megathyrsus maximus (Jacq.) B.K. Simon \& S.W.L. Jacobs] tussocks. According to the authors, the bare ground areas ranged from 45 to $20 \%$ in postgrazing and from 25 to $15 \%$ in pregrazing conditions during the experimental period. Differences in bare ground space between sod-forming bermudagrass and tussock-forming Massai, as well as differences in the colonization of such spaces by Amarillo and Ac-01, could explain the contrasting results.

Despite the absence of stubble height effects, pintoi peanut proportion in HM increased during the $2 \mathrm{yr}$ after overseeding into bermudagrass. In $3 \mathrm{yr}$ of evaluation, Ibrahim and 't Mannetje (1998) reported decreasing proportions of Stylosanthes guianensis (Aubl.) Sw. and Centrosema macrocarpum Benth. when mixed with tropical grasses in Costa Rica, suggesting the lack of persistence of these legumes in mixtures. Conversely, the authors

Table 2. Plant density and ground cover of Amarillo pintoi peanut in mixture with Jiggs bermudagrass as affected by stubble heights or months. Data are the least square means across 2 yr of study.

\begin{tabular}{|c|c|c|c|c|c|c|c|c|c|c|}
\hline \multirow[b]{2}{*}{ Response variable } & \multicolumn{2}{|c|}{ Stubble height $†$} & \multirow[b]{2}{*}{ SE } & \multirow[b]{2}{*}{$P$-value $\ddagger$} & \multicolumn{4}{|c|}{ Month } & \multirow[b]{2}{*}{ SE } & \multirow[b]{2}{*}{$P$-value§ } \\
\hline & $\mathrm{SH} 15$ & $\mathrm{SH} 25$ & & & June & July & Aug. & Sept. & & \\
\hline Plant density (plants $\mathrm{m}^{-2}$ ) & 5.9 & 5.6 & 0.48 & 0.43 & $4.9 \mathrm{~b}$ & $5.0 \mathrm{~b}$ & $7.4 a$ & $5.8 a b$ & 0.58 & $<0.01$ \\
\hline Ground cover (\%) & 5.8 & 5.9 & 2.30 & 0.50 & $4.2 \mathrm{~b}$ & $4.3 b$ & $8.6 a$ & $6.5 b$ & 2.40 & $<0.01$ \\
\hline
\end{tabular}

† SH15, average stubble height of $14.8 \mathrm{~cm}$; SH25, average stubble height of $22.0 \mathrm{~cm}$.

$\ddagger P$-value refers to the effect of stubble height in each variable.

$\S P$-value refers to the effect of month in each variable.

I Means followed by similar lowercase letters within rows are not different $(P<0.10)$ 
reported constant or increasing proportions of pintoi peanut in the same mixtures, indicating greater persistence of this legume.

In the current study, pintoi peanut was established without $\mathrm{N}$ fertilization. Some studies have shown positive effects on legume biomass with this practice (Hojjati et al., 1978; Woodman et al., 1998). However, negative effects on nodulation and biological $\mathrm{N}_{2}$ fixation have been reported as well (Woodman et al., 1998). Thomas (1994) observed that $\mathrm{N}$ fertilizations up to $50 \mathrm{~kg} \mathrm{ha}^{-1}$ may increase aboveground biomass of pintoi peanut grown as a monoculture in pots; however, further research is necessary to understand the effects of such a practice in grass-legume mixtures in field conditions.

Weed proportion in ground cover was greater for SH25 than for SH15, although the same effect was not observed on the proportion of weeds in HM (Table 3). There was no effect of overseeding on the proportion of weeds in ground cover and HM. Vaseygrass (Paspalum urvillei Steud.) was the main weed species observed in the $\mathrm{SH} 25$, which tends to increase in pastures managed under low intensity (Newman et al., 2003). The proportion of weeds in ground cover was close to or greater than what was observed by Aguiar et al. (2014) in Jiggs pastures managed under different stocking rates. Weed invasion is still a critical subject in pintoi peanut pastures, as there are no herbicides currently registered for selective weed control in the United States.

\section{Herbage Accumulation Rate}

There was no effect of sward type on HAR (Table 4), likely due to the minimum contribution of pintoi peanut in the $\mathrm{HM}$ and, consequently, in the $\mathrm{N}$ supply to the mixture. According to Unkovich et al. (2008), plant growth is the

Table 3. Percentage of weeds in ground cover and proportion in herbage mass (HM) as affected by sward type and stubble height treatments. Response variables were measured at the end of the experiment in 2015.

\begin{tabular}{lcc}
\hline & \multicolumn{2}{c}{ Weeds } \\
\cline { 2 - 3 } Treatment $\dagger$ & Ground cover & Proportion in HM \\
\cline { 2 - 3 } Sward type & & \\
Jiggs & 30.9 & 13.4 \\
Jiggs-pintoi & 40.6 & 19.7 \\
SE & 5.00 & 4.41 \\
P-valueł & 0.13 & 0.26 \\
Stubble height & & \\
SH15 & 18.2 & 12.3 \\
SH25 & 53.4 & 20.7 \\
SE & 4.70 & 4.41 \\
P-value & $<0.01$ & 0.19 \\
\hline
\end{tabular}

† Jiggs, Jiggs bermudagrass monoculture; Jiggs-pintoi, Jiggs bermudagrass pastures overseeded with Amarillo pintoi peanut; $\mathrm{SH} 15$, average stubble height of $14.8 \mathrm{~cm}$; SH25, average stubble height of $22.0 \mathrm{~cm}$.

$\ddagger P$-value refers to the effect of either sward type or stubble height treatments within each response variable. main determinant of $\mathrm{N}$ fixation when no other limitations like nutrient deficiency or unfavorable edaphic-climatic conditions are present. Low $\mathrm{N}$ fixation rates were also reported by Thomas et al. (1997), who evaluated the $\mathrm{N}$ fixation of pintoi peanut in mixture with Urochloa dictyoneura (Fig. \& De Not.) Veldkamp. The authors reported averages ranging from 0.7 to $7.4 \mathrm{~kg} \mathrm{~N} \mathrm{ha}^{-1}$ in a 12 -wk period and related the low values to the low legume proportion in HM (ranging from 1.9 to $17.7 \%$ ) rather than the proportion of biologically fixed $\mathrm{N}_{2}$ in total $\mathrm{N}$ (ranging from 57 to $88 \%$ ).

There was a stubble height $\times$ month effect for HAR (Table 5). The interaction occurred because HAR decreased from June to September in both stubble height treatments; however, the decrease was greater for SH15 than SH25 from June to July, with greater variation for SH15 in the subsequent months. The decrease in HAR from June to September was due to less favorable temperature and rainfall (Table 2), and similar trends were observed in other bermudagrass trials (Sinclair et al., 2003). The lesser HAR in the SH25 treatment likely occurred due to the excessive HM, which may result in self-shading, accumulation of senescent and nonphotosynthetic residue, and reduced photosynthesis, especially on the young basal tillers (Adjei et al., 1980; Parsons et al., 1988).

The lesser HAR than observed by Aguiar et al. (2014) in Jiggs bermudagrass $\left(\sim 70 \mathrm{~kg} \mathrm{ha}^{-1} \mathrm{~d}^{-1}\right)$ is due to the lack of $\mathrm{N}$ fertilization in the current study.

\section{Herbage Mass}

Post- and pregrazing HM were not affected by sward type (Table 4), although they were affected by stubble height $\times$ month interactions (Table 5). Postgrazing HM decreased from June to September for both stubble height treatments; however, in the SH15 treatment, it decreased from June to August and did not change from August to September, whereas for SH25, it decreased from June to July with no difference among July, August, and September. Postgrazing HM was greater in SH25 than in SH15 for all months. For pregrazing, both stubble height treatments decreased in HM from June to September; however, the magnitude of the decrease was greater for SH15. The pregrazing HM was similar between the stubble height treatments in June, but less for SH15 than for SH25 in the following months.

The lack of sward type effect on both post- and pregrazing HM is likely related to the low contribution of the legume in the canopy. Similarly, the decrease in postand pregrazing HM across the months is consistent with the decrease in HAR for both stubble height treatments. The greater postgrazing HM observed in SH25 is a result of the taller stubble height. The HM ranges observed in the present experiment are similar to the values reported by Aguiar et al. (2014). 
Table 4. Canopy variables as affected by sward type. Sward types were Jiggs bermudagrass monocultures or overseeded with Amarillo pintoi peanut. Data are least square means across two stubble height treatments, $4 \mathrm{mo}$, and $2 \mathrm{yr}$ of study.

\begin{tabular}{|c|c|c|c|c|c|c|c|}
\hline \multirow[b]{3}{*}{ Sward type } & \multicolumn{7}{|c|}{ Canopy variable† } \\
\hline & \multirow[b]{2}{*}{ HAR } & \multicolumn{2}{|c|}{ Herbage mass } & \multirow{2}{*}{$\begin{array}{c}\text { Pregrazing } \\
\text { canopy height }\end{array}$} & \multirow{2}{*}{$\begin{array}{l}\text { Pregrazing light } \\
\text { interception }\end{array}$} & \multicolumn{2}{|c|}{ Nutritive value } \\
\hline & & Postgrazing & Pregrazing & & & $\mathrm{CP}$ & IVDOM \\
\hline & $\mathrm{kg} \mathrm{ha}^{-1} \mathrm{~d}^{-1}$ & $\mathrm{Mg} \mathrm{ha}^{-1}$ & $-1-$ & $\mathrm{cm}$ & $\%$ & $\longrightarrow$ & 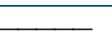 \\
\hline Jiggs & 28 & 3.2 & 4.0 & 23.7 & 88.3 & 103 & 437 \\
\hline Jiggs-pintoi & 19 & 3.3 & 3.8 & 21.9 & 88.1 & 98 & 424 \\
\hline SE & 21.3 & 0.28 & 0.75 & 0.72 & 1.89 & 2.8 & 3.8 \\
\hline$P$-value & 0.20 & 0.90 & 0.44 & 0.11 & 0.91 & 0.17 & 0.35 \\
\hline
\end{tabular}

† HAR, herbage accumulation rate; CP, crude protein concentration on a dry matter basis; IVDOM, in vitro digestible organic matter concentration in dry matter basis.

‡ Jiggs, Jiggs bermudagrass monoculture; Jiggs-pintoi, Jiggs bermudagrass pastures overseeded with Amarillo pintoi peanut.

$\S P$-value refers to the effect of sward type in each variable.

\section{Canopy Height}

Overseeding pintoi peanut did not affect pregrazing canopy height (Table 4); however, this response variable was affected by a stubble height $\times$ month interaction (Table 5). Pregrazing canopy height of SH15 did not differ from June to August, decreasing in September, whereas it decreased from June to August in SH25. Pregrazing canopy heights of SH15 and SH25 were not different, except in June, when SH25 was taller than SH15.

Decreases in pregrazing canopy height in both treatments are likely related to decreases in HAR; however, SH15 had a greater decrease in HAR and a lesser decrease

Table 5. Herbage accumulation rate (HAR) and post- and pregrazing herbage masses (HM) as affected by stubble height $\times$ month interaction. Data are least square means across 2 yr of study.

\begin{tabular}{|c|c|c|c|c|c|}
\hline \multirow[b]{2}{*}{ Variable† } & \multicolumn{4}{|c|}{ Month } & \multirow[b]{2}{*}{ SE } \\
\hline & June & July & Aug. & Sept. & \\
\hline & \multicolumn{5}{|c|}{ HAR } \\
\hline & \multicolumn{5}{|c|}{$\mathrm{kg} \mathrm{ha}^{-1} \mathrm{~d}^{-1}$} \\
\hline SH15 & 53ał & $14 c$ & $33 b$ & $18 \mathrm{c}$ & 21.8 \\
\hline $\mathrm{SH} 25$ & $26 a$ & $17 a b$ & $17 a b$ & $10 \mathrm{~b}$ & \\
\hline \multirow[t]{3}{*}{$P$-value§ } & $<0.01$ & 0.79 & 0.08 & 0.37 & \\
\hline & \multicolumn{5}{|c|}{ Postgrazing HM } \\
\hline & 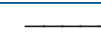 & 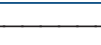 & $\operatorname{Mg~ha}^{-1}$ & & 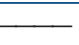 \\
\hline $\mathrm{SH} 15$ & $3.2 \mathrm{a}$ & $2.7 \mathrm{~b}$ & $1.9 c$ & $2.3 c$ & 0.32 \\
\hline $\mathrm{SH} 25$ & $4.4 a$ & $3.9 b$ & $3.9 b$ & $3.7 b$ & \\
\hline \multirow[t]{3}{*}{$P$-value } & $<0.01$ & $<0.01$ & $<0.01$ & $<0.01$ & \\
\hline & \multicolumn{5}{|c|}{ Pregrazing HM } \\
\hline & $\longrightarrow$ & - & $\mathrm{Mg} \mathrm{ha}^{-1}$ & 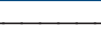 & - \\
\hline $\mathrm{SH} 15$ & $4.7 a$ & $3.1 b$ & $2.8 \mathrm{bc}$ & $2.8 \mathrm{c}$ & 0.76 \\
\hline $\mathrm{SH} 25$ & $5.2 \mathrm{a}$ & $4.4 b$ & $4.3 b$ & $3.9 c$ & \\
\hline \multirow[t]{3}{*}{$P$-value } & 0.27 & $<0.01$ & $<0.01$ & $<0.01$ & \\
\hline & \multicolumn{5}{|c|}{ Canopy height } \\
\hline & & & $-\mathrm{cm}-$ & 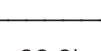 & - \\
\hline $\mathrm{SH} 15$ & $22.1 \mathrm{a}$ & $21.4 \mathrm{a}$ & $24.1 \mathrm{a}$ & $20.0 b$ & 1.10 \\
\hline $\mathrm{SH} 25$ & $25.9 a$ & $23.5 a b$ & $22.8 b$ & $22.8 b$ & \\
\hline$P$-value & 0.02 & 0.20 & 0.43 & 0.10 & \\
\hline
\end{tabular}

† SH15, average stubble height of $14.8 \mathrm{~cm}$; SH25, average stubble height of 22.0 $\mathrm{cm}$.

‡ Means followed by similar lowercase letters within rows are not different $(P<0.10)$. $\S P$-value refers to the effect of stubble height within each month for each response variable, within either post- or pregrazing conditions. in canopy height when compared with SH25. Additionally, the changes in canopy height were not consistent with the changes in post- and pregrazing HM in both stubble height treatments, indicating possible differences in canopy bulk density between the treatments. Sollenberger and Burns (2001) observed that canopy bulk density might be affected by several factors, including plant species, management practices, and weather conditions. Hodgson (1985) reported that decreases in bulk density in tropical grass canopies can be associated with lesser bite mass and, depending on the extent, lesser dry matter intake.

Considering the average postgrazing canopy heights of 15 and $22 \mathrm{~cm}$ for $\mathrm{SH} 15$ and $\mathrm{SH} 25$, the proportion of the canopy removed during the grazing events on SH15 was much greater than on SH25. In fact, to maintain the target stubble height in the SH25 treatment, the experimental units were lightly defoliated and, given the regular precipitation levels and the poor drainage capacity of the soil, the moisture and accumulation of residual biomass at the base of the canopy may have favored the appearance of spittlebug, which triggered the insecticide application. The symptoms were alleviated in the last month of the experimental period, likely due to decreased rainfall.

Even though pregrazing canopy height in this experiment was similar to or taller than that recommended by Aguiar et al. (2014), the percentage of weed ground covered was always greater, especially for the SH25 treatments. Therefore, data indicate that maintaining proper height does not assure the persistence of Jiggs independent of other factors.

\section{Light Interception}

Similar to canopy height, pregrazing LI was not affected by sward type (Table 4), although it was affected by stubble height (Table 6). Pregrazing LI was greater in SH25 than in SH15.

The greater LI for SH25 was likely caused by the greater $\mathrm{HM}$ in this treatment during 3 of the 4 mo of sampling. The HM does not fully explain the LI response, because pregrazing HM decreased throughout the growing season 
Table 6. Light interception (LI), crude protein (CP), and in vitro digestible organic matter (IVDOM) as affected by stubble heights and months. Data are least square means across 2 yr of study.

\begin{tabular}{|c|c|c|c|c|c|c|c|c|c|c|}
\hline \multirow[b]{2}{*}{ Variable } & \multicolumn{2}{|c|}{ Stubble height $†$} & \multirow[b]{2}{*}{ SE } & \multirow[b]{2}{*}{$P$-value $\ddagger$} & \multicolumn{4}{|c|}{ Month } & \multirow[b]{2}{*}{ SE } & \multirow[b]{2}{*}{$P$-value§ } \\
\hline & SH15 & $\mathrm{SH} 25$ & & & June & July & Aug. & Sept. & & \\
\hline LI (\%) & 85.2 & 91.2 & 1.89 & $<0.01$ & 87.7 & 88.6 & 87.6 & 89.0 & 1.94 & 0.67 \\
\hline $\mathrm{CP}\left(\mathrm{g} \mathrm{kg}^{-1}\right)$ & 102 & 99 & 2.8 & 0.51 & 100 & 105 & 98 & 99 & 2.9 & 0.13 \\
\hline IVDOM $\left(\mathrm{g} \mathrm{kg}^{-1}\right)$ & 443 & 418 & 38.1 & 0.08 & $444 a \prod$ & $429 b$ & $432 a b$ & $417 b$ & 38.1 & 0.05 \\
\hline
\end{tabular}

† SH15, average stubble height of $14.8 \mathrm{~cm}$; SH25, average stubble height of $22.0 \mathrm{~cm}$.

$\ddagger P$-value refers to the effect of stubble height on each response variable.

$\S P$-value refers to the effect of month on each response variable.

In Means followed by similar lowercase letters within rows are not different $(P<0.10)$.

for all treatments, but LI did not. Therefore, the differences in LI may be related to other aspects of canopy architecture. According to Braga et al. (2006), canopy height is positively related to LI, but only up to a certain point, after which height increases are associated with a nearly steady LI. Fagundes et al. (1999) compared 'Tifton 85', 'Florakirk', and 'Coast-cross' bermudagrass under continuous stocking at four grazing heights and observed that LI was $>97 \%$ in some treatments. Management practices and weather conditions may affect the relation between canopy height and LI (de Mello and Pedreira, 2004; Braga et al., 2006). The correlation coefficient between pregrazing HM and LI in this experiment was $r=0.57$, indicating a variable relationship between them.

As reviewed by da Silva and do Nascimento (2007), the maximum herbage accumulation with the least amount of senescence may occur when LI is $\sim 95 \%$. However, the mean LI in this study did not reach 95\%, even in SH25, despite the presence of senescent material $(>20 \%$ of HM, data not shown). Considering the presence of senescent material, decreased HAR, and weak relationship between LI and stubble height, the 95\% LI criterion was not an effective tool for determining when grazing should be initiated in this trial.

\section{Nutritive Value}

There was no effect of sward type on CP and IVDOM (Table 4), likely due to the low percentage of legume in the HM. Thomas (1995) estimated that a range of legume biomass of 20 to $31 \%$ of HM is needed to maintain the $\mathrm{N}$ reserves of the soil in moderately grazed pastures receiving no N fertilizer. González et al. (1996) reported increased HM, CP, and in vitro digestibility of dry matter in the biomass of stargrass (Cynodon nlemfuensis Vanderyst. var. nlemfuensis) pastures when the grass was in mixture with Amarillo. The legume proportion in the mixture ranged from 20 to $60 \%$ of HM in that study. Vendramini et al. (2013) reported increased CP but similar IVDOM and HAR for bahiagrass (Paspalum notatum Flüggé) pastures overseeded with 'Ubon' stylo (Stylosanthes guianensis var. vulgaris $\times$ var. pauciflora) vs. bahiagrass monoculture. The average legume proportion across the experiment was
$17 \%$ of HM. Although there was an increase in Amarillo proportion from 1.1 to $8.2 \%$ of HM from the first to the second year in our experiment, legume contribution was still below the threshold levels for impact suggested by Thomas (1995).

Herbage IVDOM decreased from June to September, and SH15 had greater IVDOM concentration than SH25; however, such effects were not observed in CP (Table 6). Sollenberger et al. (2012) reported that greater grazing intensity and shorter stubble heights increased forage nutritive value in $66 \%(n=41)$ of grazing trials published in the literature. Greater nutritive value is likely due to the greater proportion of younger tissue with lesser cell wall concentration. In the present experiment, the decrease in IVDOM from June to September was likely caused by high temperatures in the summer, which can increase lignin deposition and decrease forage nutritive value (Vendramini et al., 2015). Additionally, there was an accumulation of mature plant tissue, which was not uniformly removed during grazing events, especially in SH25. Vendramini et al. (2013) observed a decrease in CP and IVDOM of bahiagrass pastures from June to September at the location of the current study, and they attributed this response to high temperatures during the summer.

\section{CONCLUSIONS}

There was no effect of stubble height on pintoi peanut productivity; however, an increase in pintoi peanut proportion in the HM over the $2 \mathrm{yr}$ of study indicated that it may be a persistent warm-season legume for overseeding bermudagrass pastures. Taller stubble height $(25 \mathrm{~cm})$ did not affect pintoi peanut productivity but decreased nutritive value and increased weed proportion in the HM; therefore, it is not recommended for Jiggs bermudagrass pastures during the growing season. There was no effect of overseeding pintoi peanut on canopy height, LI, HM, HAR, $\mathrm{CP}$, and IVDOM of Jiggs bermudagrass pastures due to the limited contribution of the legume in the mixture. We conclude that pintoi peanut is adapted to overseeding in mixture with bermudagrass, and pastures should be grazed to approximately a $15-\mathrm{cm}$ stubble height when stocked rotationally. The proportion of pintoi peanut in bermudagrass 
pastures was limited in this study. Better management practices should be developed to increase the participation of pintoi peanut early in stand life so that the benefits of greater legume contribution to the forage mixture can be achieved in the long term.

\section{Conflict of Interest}

The authors declare that there is no conflict of interest.

\section{References}

Adjei, M.B., P. Mislevy, and C.Y. Ward. 1980. Response of tropical grasses to stocking rate. Agron. J. 72:863-868. doi:10.2134/ agronj1980.00021962007200060002x

Aguiar, A.D., J.M.B. Vendramini, J.D. Arthington, L.E. Sollenberger, J.M.D. Sanchez, W.L. da Silva, et al. 2014. Stocking rate effects on 'Jiggs' bermudagrass pastures grazed by heifers receiving supplementation. Crop Sci. 54:2872-2879. doi:10.2135/cropsci2014.02.0135

Blue, W.G., C.L. Dantzman, and V. Impithuksa. 1980. The response of three perennial warm-season grasses to fertilizer nitrogen on Eaugallie fine san (Elfic Haplaquod) in Central Florida. Proc. Soil Crop Sci. Soc. Fla. 39:44-47.

Boddey, R.M., J.C. De Moraes Sá, B.J.R. Alves, and S. Urquiaga. 1997. The contribution of biological nitrogen fixation for sustainable agricultural systems in the tropics. Soil Biol. Biochem. 29:787-799. doi:10.1016/S0038-0717(96)00221-0

Braga, G.J., C.G.S. Pedreira, V.R. Herling, H.D.C. Luz, and C.G. De Lima. 2006. Sward structure and herbage yield of rotationally stocked pastures of 'Marandu' palisadegrass [Brachiaria brizantha (A. Rich.) Stapf.] as affected by herbage allowance. Sci. Agric. (Piracicaba, Braz.) 63:121-129. doi:10.1590/ S0103-90162006000200003

Carvalho, M.A., and K.H. Quesenberry. 2012. Agronomic evaluation of Arachis pintoi (Krap. and Gre.) germplasm in Florida. Arch. Zootec. 61:19-29. doi:10.4321/S000405922012000100003

Castillo, M.S., L.E. Sollenberger, A.R. Blount, J.A. Ferrell, M.J. Williams, and C.L. Mackowiak. 2013. Strip planting a legume into warm-season grass pasture: Defoliation effects during the year of establishment. Crop Sci. 53:724-731. doi:10.2135/ cropsci2012.08.0485

Castillo, M.S., L.E. Sollenberger, J.A. Ferrell, A.R. Blount, C. Na, M.J. Williams, et al. 2014. Seedbed preparation techniques and weed control strategies for strip-planting rhizoma peanut into warm-season grass pastures. Crop Sci. 54:1868-1875. doi:10.2135/cropsci2013.06.0408

Cook, B.G., R.M. Jones, and R.J. Williams. 1994. Regional experience with forage Arachis in Australia. In: P.C. Kerridge and B. Hardy, editors, Biology and agronomy of forage Arachis. CIAT, Cali, Colombia. p. 158-168.

da Silva, S.C., and D. do Nascimento, Jr. 2007. Avanços na pesquisa com plantas forrageiras tropicais em pastagens: Características morfofisiológicas e manejo do pastejo (In Portuguese, with English abstract). Rev. Bras. Zootec. 36:122-138. doi:10.1590/ S1516-35982007001000014

de Andrade, C.M.S., R. Garcia, J.F. Valentim, and O.G. Pereira. 2006. Grazing management strategies for massaigrass-forage peanut pastures. 1. Dynamics of sward condition and botanical composition. Rev. Bras. Zootec. 35:334-342. doi:10.1590/ S1516-35982006000200002 de Andrade, C.M.S., R. Garcia, J.F. Valentim, and O.G. Pereira. 2012. Dynamics of sward condition and botanical composition in mixed pastures of marandugrass, forage peanut and tropical kudzu. Rev. Bras. Zootec. 41:501-511. doi:10.1590/ S1516-35982012000300005

de Assis, G.M.L., J.F. Valentim, J.M. Carneiro, J.M.A. De Azevedo, and A.S. Ferreira. 2008. Seleção de genótipos de amendoim forrageiro para cobertura do solo e produção de biomassa aérea no período de estabelecimento utilizando-se metodologia de modelos mistos (In Portuguese, with English abstract). Rev. Bras. Zootec. 37:1905-1911. doi:10.1590/ S1516-35982008001100001

de Mello, A.C.L., and C.G.S. Pedreira. 2004. Respostas morfológicas do capim-Tanzânia (Panicum maximum Jacq. cv. Tanzânia-1) irrigado à intensidade de desfolha sob lotação rotacionada (In Portuguese, with English abstract). Rev. Bras. Zootec. 33:282-289.

Fagundes, J.L., S.C. Da Silva, C.G.S. Pedreira, A.F. Sbrissia, R.A. Carnevalli, C.A.B. de Carvalho, et al. 1999. Índice da área foliar, interceptação luminosa e acúmulo de forragem em pastagens de Cynodon spp. sob diferentes intensidades de pastejo (In Portuguese, with English abstract). Sci. Agric. (Piracicaba, Brazil) 56:1141-1150. doi:10.1590/S0103-90161999000500016

Gallaher, R.N., C.O. Weldon, and J.G. Futral. 1975. An aluminum block digester for plant and soil analysis. Soil Sci. Soc. Am. J. 39:803-806. doi:10.2136/sssaj1975.03615995003900040052x

González, M.S., L.M. Van Heurck, F. Romero, D.A. Pezo, and P.J. Argel. 1996. Producción de leche en pasturas de estrella Africana (Cynodon nlemfuensis) solo y asociado con Arachis pintoi o Desmodium ovalifolium (In Spanish, with English abstract). Pasturas Trop. 18:2-12.

Hodgson, J. 1985. The control of herbage intake in the grazing ruminant. Proc. Nutr. Soc. 44:339-346. doi:10.1079/ PNS19850054

Hojjati, S.M., W.C. Templeton, Jr., and T.H. Taylor. 1978. Nitrogen fertilization in establishing forage legumes. Agron. J. 70:429433. doi:10.2134/agronj1978.00021962007000030016x

Ibrahim, M., and L. 't Mannetje. 1998. Compatibility, persistence and productivity of grass-legume mixtures in the humid tropics of Costa Rica. 1. Dry matter yield, nitrogen yield, and botanical composition. Trop. Grassl. 32:96-104.

Moore, J.E., and G.O. Mott. 1974. Recovery of residual organic matter from in vitro digestion of forages. J. Dairy Sci. 57:1258-1259. doi:10.3168/jds.S0022-0302(74)85048-4

Mullenix, M.K., L.E. Sollenberger, A.R. Blount, J.M.B. Vendramini, M.L. Silveira, and M.S. Castillo. 2014. Growth habit of rhizoma peanut affects establishment and spread when strip planted in bahiagrass pastures. Crop Sci. 54:2886-2892. doi:10.2135/cropsci2014.03.0254

Mylavarapu, R., D. Wright, G. Kidder, and C.G. Chambliss. 2013. UF/IFAS standardized fertilization recommendations for agronomic crops. SL129. Univ. Florida Inst. Food Agric. Sci., Gainesville, FL. http://edis.ifas.ufl.edu/pdffiles/SS/SS16300. pdf (accessed 12 Dec. 2017).

Newman, Y.C., L.E. Sollenberger, A.M. Fox, and C.G. Chambliss. 2003. Canopy height effects on vaseygrass and bermudagrass spread in limpograss pastures. Agron. J. 95:390-394. doi:10.2134/agronj2003.0390

Newman, Y.C., J.M.B. Vendramini, and F.A. Johnson. 2014. Bermudagrass production in Florida. SS-AGR-60. Univ. Florida Inst. Food Agric. Sci., Gainesville, FL. http://edis.ifas.ufl. edu/pdffiles/AA/AA20000.pdf (accessed 24 Nov. 2017). 
Obour, A.K., M.L. Silveira, J.M.B. Vendramini, L.E. Sollenberger, G.A. O'Connor, and J.W. Jawitz. 2011. Agronomic and environmental impacts of phosphorus fertilization of low input bahiagrass systems in Florida. Nutr. Cycl. Agroecosyst. 89:281-290. doi:10.1007/s10705-010-9393-1

Parsons, A.J., I.R. Johnson, and J.H.H. Williams. 1988. Leaf age structure and canopy photosynthesis in rotationally and continuously grazed swards. Grass Forage Sci. 43:1-14. doi:10.1111/j.1365-2494.1988.tb02136.x

Pitman, W.D., C.G. Chambliss, and A.E. Kretschmer, Jr. 1988. Persistence of tropical legumes on peninsular Florida flatwoods (Spodosols) at two stocking rates. Trop. Grassl. 22:27-33.

Rao, I.M., and P.C. Kerridge. 1994. Mineral nutrition of forage Arachis. In: P.C. Kerridge and B. Hardy, editors, Biology and agronomy of forage Arachis. CIAT, Cali, Colombia. p. 71-83.

Ribeiro, O.L., U. Cecato, A.M. Rodrigues, J.C. Faveri, G.T. dos Santos, S.M.B. Lugão, et al. 2012. Composição botânica e química da coastcross consorciada ou não com Arachis pintoi, com e sem nitrogênio (In Portuguese, with English abstract). Rev. Bras. Saude Prod. Anim. 13:47-61. doi:10.1590/S151999402012000100005

Santillan, R.A., W.R. Ocumpaugh, and G.O. Mott. 1979. Estimating forage yield with a disk meter. Agron. J. 71:71-74. doi:10.2134/agronj1979.00021962007100010017x

SAS Institute. 1996. SAS user's guide. Release 6. SAS Inst., Cary, NC.

Sinclair, K., K.F. Lowe, and K.G. Pembleton. 2007. Effect of defoliation interval and height on the growth and quality of Arachis pintoi cv. Amarillo. Trop. Grassl. 41:260-268.

Sinclair, T.R., J.D. Ray, P. Mislevy, and L.M. Premazzi. 2003. Growth of subtropical forage grasses under extended photoperiod during short-daylength months. Crop Sci. 43:618-623. doi:10.2135/cropsci2003.0618

Sollenberger, L.E., C.T. Agouridis, E.S. Vanzant, A.J. Franzluebbers, and L.B. Owens. 2012. Prescribed grazing on pasturelands. In: C.J. Nelson, editor, Conservation outcomes from pastureland and hayland practices: Assessment, recommendations, and knowledge gaps. Allen Press, Lawrence, KS. p. 111-204.

Sollenberger, L.E., and J.C. Burns. 2001. Canopy characteristics, ingestive behaviour and herbage intake in cultivated tropical grasslands. In: J.A. Gomide, W.R.S. Mattos, and S.C. Da Silva, editors, Proceedings of the 19th International Grassland Congress, São Pedro, Brazil. 10-21 Feb. 2001. Brazilian Soc. Anim. Husbandry, Piracicaba, Brazil. p. 321-327.
Taliaferro, C.M., F.M. Rouquette, Jr., and P. Mislevy. 2004. Bermudagrass and stargrass. In: L.E. Moser, B.L. Burson, and L.E. Sollenberger, editors, Warm-season $\left(\mathrm{C}_{4}\right)$ grasses. ASA, CSSA, SSSA, Madison, WI. p. 417-475. doi:10.2134/agronmonogr45.c12

Thomas, R.J. 1992. The role of the legume in the nitrogen cycle of productive and sustainable pastures. Grass Forage Sci. 47:133142. doi:10.1111/j.1365-2494.1992.tb02256.x

Thomas, R.J. 1994. Rhizobium requirements, nitrogen fixation, and nutrient cycling in forage Arachis. In: P.C. Kerridge and B. Hardy, editors, Biology and agronomy of forage Arachis. CIAT, Cali, Colombia. p. 84-94.

Thomas, R.J. 1995. Role of legumes in providing $\mathrm{N}$ for sustainable tropical pasture systems. Plant Soil 174:103-118. doi:10.1007/ BF00032243

Thomas, R.J., N.M. Asakawa, M.A. Rondon, and H.F. Alarcon. 1997. Nitrogen fixation by three tropical forage legumes in an acid-soil Savanna of Colombia. Soil Biol. Biochem. 29:801808. doi:10.1016/S0038-0717(96)00212-X

Tilley, J.A., and R.A. Terry. 1963. A two-stage technique for the in vitro digestion of forage crops. J. Br. Grassl. Soc. 18:104111. doi:10.1111/j.1365-2494.1963.tb00335.x

Unkovich, M., D. Herridge, M. Peoples, G. Cadisch, R. Boddey, K. Giller, et al. 2008. Measuring plant-associated nitrogen fixation in agricultural systems. Aust. Ctr. Int. Agric. Res., Canberra.

Vendramini, J.M.B., J.M.D. Sanchez, R.F. Cooke, A.D. Aguiar, P. Moriel, W.L. da Silva, et al. 2015. Stocking rate and monensin supplemental level effects on growth performance of beef cattle consuming warm-season grasses. J. Anim. Sci. 93:3682-3689. doi:10.2527/jas.2015-8913

Vendramini, J.M.B., M.L. Silveira, A.D. Aguiar, L. Galzerano, A.L. Valente, and P. Salvo. 2013. Forage characteristics of bahiagrass pastures overseeded with 'Ubon' stylosanthes. Forage and Grazinglands 11. doi:10.1094/FG-2013-052801-RS

Woodman, R.F., W.L. Lowther, R.P. Littlejohn, and R.F. Horrell. 1998. Establishment response of 12 legumes to nitrogen fertiliser rate and placement when direct drilled into hieracium-infested, montane tussock grasslands. N. Z. J. Agric. Res. 41:53-63. doi:10.1080/00288233.1998.9513288 